\begin{tabular}{|c|l|}
\hline Title & $\begin{array}{l}\text { The blasticidin S resistance gene (bsr) selectable in a single copy state in the bacillus subtilis } \\
\text { chromosome }\end{array}$ \\
\hline Sub Title & \\
\hline Author & $\begin{array}{l}\text { 板谷, 光弘(Itaya, Mitsuhiro) } \\
\text { 山口, 勇(Yamaguchi, Isamu) } \\
\text { 小林, 香(Kobayashi, Kaori) } \\
\text { 遠藤, 豊成(Endo, Toyoshige) } \\
\text { 田中, 暉夫(Tanaka, Teruo) }\end{array}$ \\
\hline Publisher & 共立薬科大学 \\
\hline Publication year & 1990 \\
\hline Jtitle & $\begin{array}{l}\text { 共立薬科大学研究年報 (The annual report of the Kyoritsu College of } \\
\text { Pharmacy). No.35 (1990. ),p.81-81 }\end{array}$ \\
\hline JaLC DOI & \\
\hline Abstract & \\
\hline Notes & 抄録 \\
\hline Genre & Technical Report \\
\hline URL & https://koara.lib.keio.ac.jp/xoonips/modules/xoonips/detail.php?koara_id=AN00062898-0000003 \\
\hline $5-0081$
\end{tabular}

慶應義塾大学学術情報リポジトリ(KOARA)に揭載されているコンテンツの著作権は、それぞれの著作者、学会または出版社/発行者に帰属し、その権利は著作権法によって 保護されています。引用にあたっては、著作権法を遵守してご利用ください。

The copyrights of content available on the KeiO Associated Repository of Academic resources (KOARA) belong to the respective authors, academic societies, or publishers/issuers, and these rights are protected by the Japanese Copyright Act. When quoting the content, please follow the Japanese copyright act. 


\title{
The Blasticidin S Resistance Gene (bsr) Selectable in a Single Copy State in the Bacillus subtilis Chromosome*
}

\author{
Mitsuhiro Itaya**, Isamu Yamaguchi***, Kaori Kobayashi, \\ Toyoshige ENDō, and Teruo TANAKA** \\ 板谷光弘, 山口 勇, 小林 香, 遠藤豊成, 田中瞫夫
}

The blasticidin $\mathrm{S}$ resistance gene (bsr), originally isolated from Bacillus cereus, was studied in Bacillus subtilis. It was found that a 617 bp fragment including the intact bsr gene and its 5' flanking region could confer BS resistance on $B$. subtilis when integrated in its chromosome, even in a single copy state. The construction of a $b s r$ gene cassette and its practical application as a novel selection marker for $B$. subtilis are reported.

* 本報告は J. Biochem. 107, 799-801（1990）に発表.

** 三菱化成生命科学研究所

*** 理化学研究所 